\title{
Faktor-Faktor yang Memengaruhi Keputusan Membeli Majalah Elshinta
}

\author{
Factors that Affect the Decision to Purchase the Elshinta Magazine
}

\author{
Beniko Kusumagiri ${ }^{{ }^{*}}$, Nora H. Pandjaitan ${ }^{2}$, dan Anggraini Sukmawati ${ }^{2}$ \\ ${ }^{1}$ Program Studi Industri Kecil Menengah, Institut Pertanian Bogor \\ ${ }^{2}$ Staf Pengajar Program Studi Industri Kecil Menengah, Institut Pertanian Bogor \\ Jl. Raya Pajajaran, Kampus IPB Baranangsiang Bogor 16144
}

\begin{abstract}
ABSTRAK
Di Indonesia, terdapat beberapa majalah yang membahas dunia kewirausahaan dan bisnis usaha kecil menengah (UKM). Kehadiran majalah tersebut menunjukkan bahwa pemberitaan mengenai aktivitas UKM dianggap menarik dan diminati oleh para pembaca. Tujuan penelitian ini adalah menganalisis faktor internal dan eksternal yang memengaruhi keputusan membeli majalah Elshinta serta menganalisis faktor utama yang berpengaruh dalam pembelian majalah Elshinta. Hasil analisis menunjukkan bahwa dalam mengelola media, faktor internal dan eksternal menjadi tantangan bagi pengelola Majalah Elshinta seperti mutu SDM yang tidak memadai, selain juga persaingan antar majalah, kenaikan harga bahan baku, dan minat baca masyarakat Indonesia yang rendah. Berdasarkan hasil analisis regresi linear sederhana yang diuji dengan uji t didapatkan bahwa harga, mutu produk, bauran promosi dan citra merek berpengaruh nyata dan positif secara parsial terhadap keputusan membeli majalah Elshinta. Dengan uji F didapatkan bahwa harga, mutu produk, bauran promosi dan citra merk perusahaan secara bersama-sama (simultan) dianggap penting dan berpengaruh nyata dalam meningkatkan keputusan membeli majalah Elshinta. Dari hasil analisis pengujian dengan menggunakan SPSS didapatkan bahwa terdapat pengaruh positif dan signifikan antara variabel mutu produk, bauran promosi, dan citra merk terhadap keputusan membeli majalah Elshinta.
\end{abstract}

Kata kunci: keputusan membeli, majalah Elshinta, rubrik kewirausahaan, faktor internal dan eksternal

\section{ABSTRACT}

There are numerous magazines that discuss entrepreneurship and small and medium enterprises (SMEs) in Indonesia. The presence of these magazines indicated that the activities of SMEs are considered interesting and favored by the readers. The objectives of this research were to analyze the internal and external factors which affect the decision to purchase the Elshinta magazine and to analyze major factors that affect the decision in purchasing the Elshinta magazine. The results showed that internal and external factors were a challenge in managing the magazine,such as low competency of human resources, prices of raw materials increased and reading interest of Indonesian people were low. The results of the simple linear regression analysis using t-test showed that the price, product quality, promotion mix and brand image really influenced and partially positive to the decision to purchase the Elshinta magazine. The results of F-test showed that price, product quality, promotion mix and company's brand image were simultaneously important and had real affects in increasing the decision in purchasing the Elshinta magazine. The results of the test analysis using the SPSS showed that there were positive and significant affects of variables i.e product quality, promotion mix and brand image on the decision to purchase the Elshinta magazine.

Keywords: decision to purchase, Elshinta magazine, entrepreneurship rubric, external and internal factors

*) Korespondensi

Jl. Raya Pajajaran, Kampus IPB Baranangsiang Bogor 16144; email: beniko_k@yahoo.com 


\section{PENDAHULUAN}

Para pengusaha merasa diuntungkan dengan mendirikan perusahaan yang bergerak di bidang media massa. Perusahaan media massa adalah usaha yang akan selalu dibutuhkan masyarakat sepanjang masa, karena manusia selalu membutuhkan informasi. Hal ini selaras dengan penelitian Suprapto (2009), yang menyatakan bahwa media massa memiliki peran penting dalam perkembangan masyarakat. Hal tersebut dapat dilihat dari banyaknya stasiun televisi, radio, dan perusahaan media cetak, baik berupa surat kabar maupun majalah.

Selain daripada itu, akses masyarakat terhadap informasi juga semakin mudah dengan tersedianya fasilitas internet. Namun, sampai saat ini media cetak masih menjadi salah satu sumber informasi yang disukai masyarakat meskipun akses melalui internet jauh lebih mudah dan murah (Suprapto 2009).

Media massa cetak dalam bentuk majalah telah lama dikenal masyarakat. Majalah merupakan sarana komunikasi yang dapat dimanfaatkan untuk memberikan informasi selengkap dan semenarik mungkin. Informasi yang terdapat pada majalah dikemas sedemikian rupa dalam aneka bentuk seperti liputan berita, liputan khusus, features, dan iklan sehingga menjadi menarik. Saat ini spesialisasi majalah dapat dengan mudah dijumpai. Majalah bisnis, majalah musik, majalah remaja, majalah otomotif, dan majalah yang khusus mengangkat tentang kewirausahaan dan bisnis Usaha Kecil dan Menengah (UKM) merupakan salah satu contoh, yang semuanya mempunyai misi sesuai dengan target pembaca yang diinginkan (Lestari 2010).

Di Indonesia, majalah yang menyajikan dunia kewirausahaan dan bisnis UKM adalah Majalah Elshinta, Ide Bisnis, Bisnis UKM, UKM Indonesia, Majalah Digital Bisnis UKM, Majalah Usaha Mikro Kecil dan Menengah (UMKM), dan Tabloid Info Business Opportunity Indonesia. Hadirnya beberapa majalah yang khusus mengangkat dunia kewirausahaan dan bisnis UKM ini mengisyaratkan potensi UKM Indonesia yang besar. Meski demikian aktivitas kewirausahaan, terutama yang di daerah, cenderung masih mengalami banyak hambatan antara lain dalam hal permodalan, jaringan pemasaran, penguasaan teknologi informasi, manajemen, standarisasi produk, dan mutu sumber daya manusia (Lestari 2010).
Persaingan industri majalah di Indonesia sungguh sangat ketat dan perkembangan majalah seperti yang dikatakan oleh Bonneff (1976) seperti jamur di musim hujan. Para pelaku bisnis dituntut untuk lebih cermat dalam melakukan strategi pemasaran dalam upaya untuk mempertahankan bisnisnya. Untuk itu perusahaan harus melakukan inovasi strategi pemasaran yang tepat untuk merebut pasar yang semakin dibanjiri oleh begitu banyak produk.

Menurut Shane dan Venkatarman (2000), aktivitas kewirausahaan ini sebagai suatu proses dimana semangat, sikap, kemampuan, perilaku dan wujud tindakan yang dilakukan oleh pengusaha atau calon pengusaha, merupakan rangkaian yang saling memengaruhi dan bersifat sekuensial. Hingga saat ini, kajian mengenai perilaku konsumen telah menjadi fokus dari banyak peneliti di bidang manajemen, khususnya pemasaran. Tujuannya hanya satu, yaitu mengidentifikasi faktor paling utama yang berpengaruh terhadap pola perilaku konsumen, dan kemudian akan memberikan tujuan berupa optimisasi penjualan melalui faktor tersebut.

Hartono et al. (2011) melakukan penelitian tentang perilaku konsumen pada pembelian bakso di Malang. Dengan menggunakan 120 konsumen yang dipilih berdasarkan accidental sampling, didapatkan bahwa faktor yang memberikan pengaruh nyata dan positif yang paling kuat adalah faktor harga, lingkungan, dan referensi dari pihak ketiga. Noviyarto (2010) melakukan penelitian perilaku konsumen pada paket data unlimited internet code division multiple acces (CDMA) di Jakarta. Hasil penelitiannya menunjukkan bahwa faktor psikologis merupakan penentu utama dari keputusan pembelian pada paket data ini. Faktor psikologi yang dimaksudkan adalah motivasi, pandangan, kemauan belajar, hingga kepercayaan.

Kotler et al. (2002) menyatakan bahwa perilaku pembelian konsumen dipengaruhi oleh faktor-faktor budaya, sosial, pribadi dan psikologis. Menurut Ritawati et al. (2001) perilaku konsumen dalam pembelian air minum mineral dipengaruhi secara bersama-sama dan bermakna oleh faktor pendidikan, penghasilan, harga, mutu, layanan dan promosi. Di sisi lain, harga juga masih menjadi faktor utama dari keputusan untuk membeli produk susu kental manis coklat Indomilk pada konsumen di Jakarta (Mulyana dan Syarif 2007).

Dari beberapa hasil penelitian tersebut dapat disimpulkan bahwa ada dua faktor yang 
cukup dominan dalam kajian perilaku konsumen. Faktor yang pertama adalah faktor harga dan yang kedua adalah faktor psikologis (turunannya adalah spesifikasi dari produk tersebut).

Setiap perusahaan media massa perlu melakukan strategi pemasaran, agar produknya diterima masyarakat. Pada media massa berupa majalah, terdapat beberapa faktor seperti nama, tampilan visual, produk dan harga. Untuk itu redaksi dan manajer pemasaran berjuang, agar majalahnya mendapat perhatian dari para pembacanya. Tujuan pemasaran memengaruhi keyakinan dan citra masyarakat untuk menjadi pembeli potensial. Ini hanya bisa terjadi jika perusahaan mengenal stakeholder dan kelompok sasaran dengan baik.

Majalah sebagai media massa berguna menyebarkan informasi tentang suatu peristiwa atau kejadian yang sedang menjadi topik hangat bulanan. Sebagai majalah yang berfokus pada kewirausahaan, redaksi majalah Elshinta berusaha membawa perubahan berarti dalam kehidupan dunia bisnis kewirausahaan dengan membahas sistem bisnis, pemerintahan, pendidikan, hubungan sosial dan marketing bisnis. Saat ini semakin banyaknya orang yang mencari majalah melalui internet daripada membeli majalah. Hal ini dimungkinkan, karena perkembangan majalah atau surat kabar semakin banyak dan terbukti dalam hal kemampuan menyajikan majalahmajalah aktual. Media semakin berkembang seiring dengan meningkatnya kebutuhan manusia akan informasi.

Sebagai salah satu majalah yang selalu memberikan informasi baru kepada masyarakat, majalah Elshinta tetap melakukan optimisasi pelayanan berupa rubrik bermutu kepada masyarakat. Isi rubrik pada majalah mendapat perhatian khusus dari manajemen Elshinta.

Berkembangnya persaingan dunia usaha yang menghasilkan begitu banyak usaha skala kecil dan menengah menjadi sumber informasi bagi majalah Elshinta dalam menyediakan rubrik yang menarik dan up to date bagi masyarakat. Lahirnya usahawan/wati yang baru meningkatkan kebutuhan informasi berkala yang dibutuhkan untuk terus menambah wawasan pembaca mengenai aspek kewirausahaan. Hal ini kemudian menjadi tantangan tersendiri bagi majalah Elshinta. Tujuan penelitian ini adalah menganalisis faktor-faktor internal dan eksternal yang memengaruhi keputusan membeli majalah Elshinta serta menganalisis faktor utama yang berpengaruh dalam pembelian majalah Elshinta.

\section{METODE PENELITIAN}

Pengambilan data primer dan sekunder dilakukan di kantor Majalah Elshinta di jalan Kedoya Duri Raya No. 36 Kebon Jeruk Jakarta Barat, dan dilaksanakan dari bulan Juli sampai November 2015. Pendekatan dalam penelitian ini adalah pendekatan kuantitatif. Hal ini sesuai dengan pendapat Arikunto (2006) yang mengemukakan bahwa penelitian kuantitatif adalah pendekatan penelitian yang banyak dituntut menggunakan angka, mulai dari pengumpulan data, penafsiran terhadap data tersebut, serta penampilan hasilnya.

Teknik pengambilan sampel dilakukan dengan teknik simple random. Frame sample yang digunakan adalah seluruh pembaca majalah Elshinta yang aktif dan terdaftar dalam database penerbit dengan jumlah sebesar 1.500 orang.

Jumlah responden ditentukan dengan menggunakan formula Slovin (Riduwan, 2005):

$$
n=\frac{N}{1+N e^{2}}
$$

$\mathrm{n}=$ sampel; $\mathrm{N}=$ populasi; $\mathrm{e}=$ Tingkat kesalahan penarikan sampel $10 \%$ dan tingkat kepercayaan $90 \%$. Maka N = $1.500 /\left(1+1.500(0,1)^{2}\right)=93,73$, sehingga dibulatkan menjadi 95.

Validitas kuesioner dilakukan dengan prosedur standar,yaitu prosedur untuk memastikan apakah kuesioner yang akan dipakai untuk mengukur variabel penelitian valid atau tidak. Kuesioner yang valid berarti kuesioner yang dipergunakan untuk mengumpulkan data tersebut valid. Uji t pada dasarnya menunjukkan seberapa jauh pengaruh satu variabel independen secara individual dalam menerangkan variasi variabel independen.

\section{HASIL DAN PEMBAHASAN}

Majalah Elshinta merupakan bagian dari Elshinta Media Grup yang juga memiliki Radio Elshinta dan TV Elshinta. Secara otomatis setiap penerbitan majalah Elshinta selalu disiarkan oleh Radio dan TV Elshinta, selain juga Elshinta On Line dan Twitter @MajalahElshinta. Dengan demikian informasinya tersebar luas ke seluruh Indonesia. Pembaca dapat memperoleh majalah Elshinta pada gerai Indomaret, toko buku Gramedia, toko buku Gunung Agung, serta agenagen media terdekat. Juga dapat diakses melalui iPad melalui aplikasi Scoop. Majalah Elshinta dapat dibeli hanya dengan harga Rp20.000. 
Untuk meningkatkan brand, majalah Elshinta menyelenggarakan kegiatan rutin diantaranya InspiraTrip, yaitu perjalanan wisata bernuansa bisnis. Kegiatan yang dilakukan dua kali setahun ini diikuti peserta pembaca majalah yang terdiri dari kalangan pengusaha, pemula dan yang berminat membuka usaha. Peserta bertemu dan sharing bisnis langsung dengan pemilik industri di daerah yang menjadi tujuan. Selain membangun jaringan bisnis, peserta juga mendapat pencerahan melalui seminar yang diberikan oleh pakar bisnis. InspiraTrip dilaksanakan pada April 2011 ke Yogyakarta, Juli 2011 ke Bandung dan April 2012 ke Bali.

\section{Faktor Internal}

Faktor-faktor internal yang memengaruhi keputusan membeli pada Majalah Elshinta, yaitu: 1. Harga

Harga eceran Majalah Elshinta saat penelitian ini dilakukan (Oktober 2015) relatif lebih terjangkau dibandingkan dengan harga majalah lokal yang terbit dan beredar di Kota Jakarta. Harga eceran Majalah Elshinta yakni Rp20.000 per eksemplar. Harga langganan Majalah Elshinta Rp108.000 per enam bulan dan Rp204.000 per tahun. Harga tersebut merupakan harga yang masih wajar untuk harga majalah, terutama bagi segmen konsumen di Jakarta.

\section{Kecepatan terbit}

Majalah Elshinta semuanya dicetak oleh percetakan di Jl. Kedoya Duri Raya Jakarta Barat. Penerbitan majalah ini dilakukan setiap bulan. Majalah Elshinta diterbitkan oleh PT Gramedia.

\section{Konten}

Persaingan bisnis majalah di Kota Jakarta telah mendorong pengelola Majalah Elshinta untuk selalu menyajikan konten dan desain yang dianggap dapat diterima pasar. Pasar yang dimaksud adalah publik sebagai pembeli dan pemasang iklan. Pembeli serta pemasang iklan sangat menentukan kelangsungan bisnis Majalah Elshinta. Menyikapi persaingan itu, Manager Produksi Majalah Elshinta mengatakan bahwa Majalah Elshinta hadir dengan konsep majalah kewirausahaan. Hal tersebut dimaksudkan untuk mendapatkan pembaca yang beragam, baik dari ragam profesi/pekerjaan, partai politik, suku, agama, ras, pendidikan, hobi/selera, hingga ragam tingkat usia. Oleh karena itu isi majalahnya juga beragam. Selain berita kewirausahaan juga terdapat berita politik, berita ekonomi, berita cover, rubrikasi, maestro, pencerahan dalam negeri, pencerahan luar negeri, prospek, UKM, franchise, bisnis unik, tips/trik, konsultasi, tamu, bisnis selebritis, potensi daerah, sentra bisnis, komunitas, expo file, mediasi, pojok Elshinta, TTS/Sudoku hingga kisah-kisah inspiratif dari orang-orang sukses serta gaya hidup seseorang.

Ketertarikan para pembeli majalah ini juga disebabkan adanya rubrik profil pengusaha besar dan sukses. Penulisan menggunakan gaya wawancara dan deskripsi/narasi serta menekankan pada sisi motivasi dan inspirasi. Informasi yang disampaikan berupa seputar pengalaman hidup dan bisnis, kiat-kiat sukses, dan filosofi. Hal ini menyemangati pembaca dalam menjalankan usahanya dan diharapkan pembaca akan tertarik untuk dapat mengikuti jejaknya bahkan menjalin hubungan di dunia bisnis.

4. Brand

Brand Majalah Elshinta sangat dikenal masyarakat Kota Jakarta pada khususnya, maupun di sekitarnya secara umum, bahkan dikenal secara nasional. Hal ini disebabkan Majalah Elshinta sudah lama terbit (lebih dari 10 tahun). Selain karena faktor usia majalah ini juga mampu beradaptasi dengan pertumbuhan media online maupun media sosial dengan melakukan konvergensi media. Salah satu wujud konvergensi yang dimaksud adalah hadirnya www.elshinta. com dan adanya akun media sosial di Facebook dan Twitter.

5. Isi kewirausahaan

Desain dan konten yang disajikan Majalah Elshinta selama ini disukai banyak orang/pembacanya. Berdasarkan analisis deskriptif terhadap peran rubrik kewirausahaan terhadap minat pembelian Majalah Elshinta menunjukkan bahwa rataan responden yang setia membeli majalah Elshinta mengungkapkan tertarik untuk membeli majalah karena tampilan covernya. Cover Majalah Elshinta menampilkan tokoh-tokoh yang terkenal dan sukses dalam bidang kewirausahaan. Selain itu Majalah Elshinta relatif mudah dibawa dan konten Majalah Elshinta Up to Date.

Ketertarikan pembeli juga disebabkan isi rubrik kewirausahaan Majalah Elshinta, yaitu: (1) informasi peluang usaha yang ditulis dengan tema tertentu tentang jenis-jenis usaha yang saling terkait; (2) informasi usaha menyangkut permodalan; (3) cara menjalankan usaha; (4) omzet yang diperoleh; dan (5) informasi UKM yang potensial dan layak untuk ditekuni meliputi profit, kendala, masalah-masalah khusus, gejala atau trend di dunia usaha kecil dan menengah. 


\section{Faktor Eksternal}

1. Kompetisi pasar

Dalam perspektif ekonomi media, media massa berkompetisi memperebutkan pasar. Pasar media adalah khalayak dan pengiklan, dengan begitu, dalam perspektif ekonomi media, media massa bersaing memperebutkan khalayak dan pengiklan. Dalam tataran praktis, selera pasar senantiasa berubah dan berkembang. Selera khalayak dan pengiklan berkembang dari waktu ke waktu. Media sebagai institusi ekonomi harus mampu mengidentifikasi selera pasar dan perkembangannya. Dengan mengetahui selera pasar dan perubahannya, majalah Elshinta akan mampu beradaptasi dan memenuhi keinginan pasar. Hanya media yang mampu memenuhi keinginan dan kebutuhan pasar yang dapat bertahan dalam dunia ekonomi yang penuh persaingan ini.

\section{Media Online}

Kehadiran media online lokal di kota maupun media online berjejaring yang berkantor pusat di Jakarta, juga harus diakui telah banyak menyedot pembaca. Jumlah pembaca yang sengaja mencari informasi melalui internet terus meningkat. Pertumbuhan jumlah pembaca media online disebabkan informasi melalui media online semakin mudah dan murah. Hal ini didukung pula oleh harga perangkat keras (hard ware) untuk mengakses media online semakin terjangkau. Kebanyakan media online tidak mengenakan bayaran bagi para pengaksesnya.

Kondisi tersebut, bagi pengelola Majalah Elshinta adalah tantangan berat. Disamping itu sebagian warga kota terutama kalangan remaja dan anak muda yang usia kisaran 17-40 tahun, merasa kebutuhan informasinya sudah terpenuhi dengan membaca media-media online yang diaksesnya melalui ipad, laptop, tablet, maupun smartphone. Sebagian diantaranya pada akhirnya merasa tidak perlu lagi membeli apalagi berlangganan surat kabar harian lokal, terlebih koran nasional.

3. Harga Bahan Baku

Tantangan atau masalah berat yang kini dihadapi pengelola industri surat majalah adalah harga bahan baku terutama kertas yang setiap tahunnya di pasaran terus naik seiring kenaikan harga bahan bakar minyak (BBM). Terlebih pada saat menurunnya nilai tukar rupiah terhadap dolar AS, padahal kertas adalah bahan baku utama bisnis surat kabar harian. Kenaikan harga BBM juga mengakibatkan meningkatnya biaya operasional percetakan dan distribusi koran ke pelanggan.

Masalah lain yang turut dihadapi pengelola industri surat kabar adalah iklan untuk media massa juga semakin terbatas. Seiring bertambahnya media massa baru yang hadir, iklan tidak lagi hanya ditampilkan di televisi, radio, surat kabar, majalah dan tabloid, tetapi juga melalui media-media online.

\section{Strategi yang telah dilakukan Majalah Elshinta}

Menurut Manager Produksi Majalah Elshinta, satu di antara strategi yang dilakukan Majalah Elshinta sejak awal hadir sampai saat ini, yaitu menggunakan konsep sebagai Majalah Enterpreneur/kewirausahaan. Hal tersebut dimaksudkan untuk menyasar pembaca yang beragam, baik dari ragam profesi/pekerjaan, partai politik, suku, agama, ras, pendidikan, hobi/selera, hingga ragam tingkat usia. Oleh karena itu konten kewirausahaan Majalah Elshinta beragam.

Memosisikan diri sebagai majalah entrepreneur/kewirausahaan adalah strategi yang sangat tepat. Hal ini dilakukan karena yang ingin dicapai adalah jumlah pembaca yang banyak. Sebagai majalah enterpreneur/kewirausahaan, maka pembaca Majalah Elshinta bisa dipastikan beragam, mulai dari anak-anak, remaja, dewasa, hingga orangtua, baik laki-laki maupun perempuan. Selain itu, konten kewirausahaan Majalah Elshinta harus dapat dijual (marketable), berarti harus sesuai selera pasar atau kesukaan pelanggan/pembaca. Dengan demikian jika berita itu disajikan, dipastikan penjualan meningkat dan pembaca bertambah. Beberapa syarat berita marketable antara lain: (1) informasi yang disajikan memiliki nilai berita yang kuat, yaitu berita baru atau aktual; (2) melibatkan orang-orang terkenal, unik, langka/tidak lazim atau human interest-nya kuat dan menarik; dan (3) proximity atau memiliki kedekatan psikografi, atau bisa juga kedekatan ideologi.

Format penyajian isi kewirausahaan Majalah Elshinta berbeda dengan format isi majalah cetak lainnya. Format penyajian konten kewirausahaan Majalah Elshinta ada standar baku, yaitu di setiap rubrik berita, harus menjadi headline utamanya. Pada berita dengan kategori headline (berita utama), minimal harus ada overallnya, sidebar-nya, pull out. Sering juga dilengkapi foto dan data pendukung disajikan dalam bentuk point to point dan grafis. Panjang berita overall umumnya antara 7-8 paragraf, sedangkan sidebar 
antara 2-4 paragraf. Berita non-headline, disajikan maksimal 8 paragraf dan tidak panjang.

Strategi lain yang dilakukan Majalah Elshinta adalah memperkuat brand, dengan cara memperluas penyebaran konten yang dimiliki Majalah Elshinta melalui cross media yakni melalui website www.elshinta.com, akun media sosial (Facebook, Twitter dan Pinterest) yang dikelola Elshinta, radio jaringan, serta televisi internet milik Elshinta yang ditempatkan di beberapa minimarket.

Untuk menjangkau pembaca lebih banyak, manajemen Majalah Elshinta menerapkan harga majalah yang dianggap terjangkau. Oleh karena itu, pengelola Majalah Elshinta menerapkan harga majalah di tingkat eceran senilai Rp20.000 per eksemplar. Harga ini sudah berlaku sejak beberapa tahun terakhir. Kendati hampir setiap tahun, harga bahan baku seperti kertas dan bahan bakar minyak (BBM) serta biaya produksi lainnya naik.

Selain itu strategi yang dilakukan bagian promosi Majalah Elshinta antara lain membangun top brand di warga Kota pada khususnya dan masyarakat Jakarta dan sekitarnya pada umumnya. Hal tersebut dilakukan dengan cara menggelar event besar yang sifatnya masif, menjalin kerja sama dengan perusahaan-perusahaan, komunitas, maupun dengan media-media mainstream lain, yakni radio dan televisi, baik yang ada di Kota Jakarta maupun media nasional. Strategi lain yang dilakukan bagian Promosi Majalah Elshinta adalah dengan menjalin kerja sama dengan komunitas online. Misalnya pengguna akun Facebook dan Twitter yang memiliki LikeFage maupun follower (pengikut) yang besar di Kota Jakarta. Tujuan strategi tersebut meningkatkan brand image Majalah Elshinta kepada komunitas online sekaligus menjaring pembaca-pembaca baru dan muda.

\section{Faktor yang Berpengaruh dalam Pembelian Majalah Elshinta}

\section{Uji Validitas}

Uji validitas digunakan untuk mengukur valid atau tidaknya suatu kuesioner. Suatu kuesioner dikatakan valid jika pertanyaan pada kuesioner mampu untuk mengungkapkan sesuatu yang akan diukur oleh kuesioner tersebut. Pengujian validitas dalam penelitian ini dilakukan dengan membandingkan nilai $r$-hitung dengan nilai $\mathrm{r}$-tabel. Nilai $\mathrm{r}$-hitung diambil dari output SPSS Cronbach Alpha pada kolom corrected item-total correlation. Nilai $\mathrm{r}$-tabel diambil dengan meng- gunakan rumusdf $=\mathrm{n}-2$, yaitu $100-2=98$ dan taraf nyata $5 \%$ sehingga menghasilkan nilai $r$-tabel 0.197

Untuk mengetahui hasil lengkap dari uji validitas setiap r-butir pertanyaan dapat dilihat sebagai berikut:

1. Hasil Uji Validitas terhadap Harga $\left(X_{1}\right)$

Uji validitas terhadap kompetensi pemimpin yang dilakukan pada 200 responden dengan jumlah indikator sembilan. Nilai corrected-Total Correlation menunjukan rentang nilai sebesar 0.433 sampai 0.651, dimana angka corrected-Total Correlation di atas nilai rtabel sebesar 0.197 ( $\mathrm{r}$-hitung $>$ $\mathrm{r}$-tabel), artinya setelah dibandingkan dengan nilai alpha cronbatch's (rhitung) ternyata semua pertanyaan pada harga adalah valid.

2. Hasil uji validitas terhadap Mutu Produk $\left(\mathrm{X}_{2}\right)$

Uji validitas terhadap mutu produk yang dilakukan pada 100 responden dengan jumlah indikator 14. Nilai corrected-Total Correlation menunjukan rentang nilai 0.333-0.707, dimana angka corrected-Total Correlation di atas nilai rabel 0.197 ( $\mathrm{r}$-hitung $>\mathrm{r}$-tabel), artinya setelah dibandingkan dengan nilai alpha cronbatch's (rhitung) ternyata semua pertanyaan pada mutu produk adalah valid.

3. Hasil Uji Validitas Terhadap Bauran Promosi $\left(\mathrm{X}_{3}\right)$

Uji validitas terhadap Citra Merk yang dilakukan pada 100 responden dengan jumlah indikator tujuh. Nilai corrected-Total Correlation menunjukan rentang nilai sebesar 0.485-0.771, dimana angka corrected-Total Correlation di atas nilai rtabel 0.197 (r-hitung $>\mathrm{r}$-tabel), artinya setelah dibandingkan dengan nilai alpha cronbatch's (rhitung) ternyata semua pertanyaan pada bauran promosi adalah valid.

4. Hasil Uji Validitas Terhadap Citra Merk (X4)

Uji validitas terhadap citra merk yang dilakukan pada 100 responden dengan jumlah indikator lima. Nilai corrected-Total Correlation menunjukan rentang nilai 0.479-0.586, dimana angka corrected-Total Correlation di atas nilai rabel 0.197(r-hitung $>\mathrm{r}$-tabel), artinya setelah dibandingkan dengan nilai alpha cronbatch's (rhitung) ternyata semua pertanyaan pada citra merk adalah valid. 5. Hasil Uji Validitas Terhadap Keputusan Membeli (Y)

Uji validitas terhadap keputusan membeli yang dilakukan pada 100 responden dengan jumlah indikator delapan. Nilai corrected-Total Correlation menunjukan rentang nilai 0.377-0.614, dimana angka corrected-Total Correlation di atas nilai rtabel 0.197 (r-hitung $>\mathrm{r}$-tabel), artinya setelah 
dibandingkan dengan nilai alpha cronbatch's (rhitung) ternyata semua pertanyaan pada keputusan membeli adalah valid.

Setelah dilakukan analisa dengan bantuan program SPSS ver. 16.00 dengan analisis reliabiliti, diperoleh hasil (Tabel 1) berikut:

1. Harga $\left(X_{1}\right)$

Berdasarkan ketentuan, jika nilai Cornbach's Alpha menunjukkan reliability statistik sama dengan atau lebih besar dari 0.60 maka pertanyaan tersebut adalah reliable (dapat diandalkan). Nilai reliabilitas yang diperoleh dengan model Cronbach's Alpha 0.804 dan daerah titik kritis penerimaan 0.60 , sehingga $0.804>0.60$, maka pertanyaan-pertanyaan pada kompetensi pemimpin reliable (dapat dihandalkan).

2. Mutu Produk $\left(\mathrm{X}_{2}\right)$

Berdasarkan ketentuan, jika nilai Cornbach's Alpha menunjukkan realiability statistik sama dengan atau lebih besar dari 0.60, maka pertanyaan tersebut adalah reliable. Nilai reliabilitas yang diperoleh dengan model Cronbach's Alpha sebesar 0.838 dan daerah titik kritis penerimaan 0.60 , sehingga $0.838>0.60$, maka pertanyaan-pertanyaan pada mutu produk reliable.

\section{Mutu Bauran Promosi $\left(\mathrm{X}_{3}\right)$}

Berdasarkan ketentuan, jika nilai Cornbach's Alpha menunjukkan realiability statistik sama dengan atau lebih besar dari 0.60, maka pertanyaan tersebut adalah reliable. Nilai reliabilitas yang diperoleh dengan model Cronbach's Alpha sebesar 0.890 dan daerah titik kritis penerimaan 0.60 , sehingga $0.890>0.60$, maka pertanyaan-pertanyaan pada bauran promosi reliable.

4. Mutu Citra Merk $\left(X_{4}\right)$

Berdasarkan ketentuan, jika nilai Cornbach's Alpha menunjukkan realiability statistik sama dengan atau lebih besar dari 0.60, maka pertanyaan tersebut adalah reliable. Nilai reliabilitas yang diperoleh dengan model Cronbach's Alpha 0.759 dan daerah titik kritis penerimaan 0.60 , sehingga $0.759>0.60$, maka pertanyaan-pertanyaan pada citra merk reliable.

5. Variabel Keputusan Membeli (Y)

Berdasarkan ketentuan, jika nilai Cornbach's Alpha menunjukkan realiability statistik sama dengan atau lebih besar dari 0. 60, maka pertanyaan reliable. Nilai reliabilitas yang diperoleh dengan model Cronbach's Alpha 0.715 dan daerah titik kritis penerimaan 0.60 , sehingga $0.715>0.60$, maka pertanyaan-pertanyaan pada keputusan membeli reliable.
Tabel 1. Uji reliabilitas variabel

\begin{tabular}{cccc}
\hline $\begin{array}{c}\text { Cronbach's } \\
\text { Alpha }\end{array}$ & $\begin{array}{c}\text { Titik } \\
\text { Kritis }\end{array}$ & Keputusan & Keterangan \\
\hline 0.804 & 0.60 & Ho ditolak & Reliable \\
0.838 & 0.60 & Ho ditolak & Reliable \\
0.890 & 0.60 & Ho ditolak & Reliable \\
0.759 & 0.60 & Ho ditolak & Reliable \\
0.715 & 0.60 & Ho ditolak & Reliable \\
\hline
\end{tabular}

\section{Uji Asumsi Klasik}

1. Uji Normalitas Data

Uji normalitas bertujuan menganalsis model regresi, variabel pengganggu atau residual memiliki distribusi normal atau tidak. Model data yang baik adalah berdistribusi normal atau mendekati normal. Untuk melihat data berdistribusi normal dilakukan dengan memperhatikan normal probability plot pada scatter plot berdistribusi normal.

Berdasarkan hasil analisis regresi linear terlihat bahwa garis membentuk garis kurva normal dengan nilai standar deviasi 0.98. Hasil P$P$ Plot menunjukkan semua data berdistribusi normal, karena semua data menyebar dan membentuk garis lurus searah dengan garis diagonal, maka data tersebut memenuhi asumsi normal atau mengikuti garis normalitas.

2. Uji Linearitas

Uji asumsi linieritas dilakukan dengan cara membuat plot residual yang telah distandarisasi dengan nilai perkiraan variabel dependen terstandarisasi yang diberi nama scatterplots of residuals. Terdapat hubungan 95\% dari residual terletak antara $-2,5$ dan $+2,5$, maka asumsi linieritas dipenuhi.

3. Uji Multikolinearitas

Hasil uji multikolinearitas menunjukkan variabel independen harga memiliki nilai tolerance 0.111 dan nilai VIF 9.040. Variabel independen mutu produk memiliki nilai tolerance 0.557 dan nilai VIF 1.796. Variabel independen bauran promosi memiliki nilai tolerance 0.285 dan nilai VIF 3.512. Variabel independen citra merk memiliki nilai tolerance 0.199 dan nilai VIF sebesar 9.087. Dari uji tersebut dapat diketahui bahwa nilai tolerance keempat variabel independen lebih besar dari 0,10 (tolerance $>0,10$ ) dan nilai VIF keempat variabel independen kurang dari 10 (VIF< 10), maka dapat disimpulkan model regresi tidak terdapat gejala multikolinearitas.

4. Uji Heteroskedastisitas

Asumsi ini menyatakan bahwa variansi residual di sekitar garis regresi adalah konstan untuk setiap kombinasi dari nilai variabel 
independennya. Jika dalam regresi grafik scatterplots of residuals tidak membentuk pola tertentu (bergelombang, melebar kemudian menyempit, pola linear atau kuadratis), maka scatterplot Chart dalam tidak membentuk pola tertentu, sehingga regresi asumsi tidak terjadi heteroskedastisitas dipenuhi.

Hasil uji heteroskedastisitas menunjukkan harga, mutu produk, bauran promosi, citra merk dan keputusan membeli. Dari Grafik scatterplot menunjukan bahwa titik-titik butir menyebar berada di daerah $-2,5$ dan $+2,5$ dan tidak membentuk pola tertentu, sehingga asumsi tidak terjadi heteroskedastisitas terpenuhi.

Analisis regresi digunakan untuk mengetahui ada atau tidak dan besarnya pengaruh variabel bebas terhadap variabel terikat. Variabelvariabel yang diuji adalah harga, mutu produk, bauran promosi, citra merk, dan keputusan membeli. Dalam penelitian ini analisis regresi yang digunakan adalah analisis regresi linear sederhana dan regresi linear berganda.

\section{Uji Regresi Linear Sederhana}

1. Harga Terhadap Keputusan Membeli

Hasil regresi dapat dilihat bahwa besarnya nilai konstanta (nilai a) sebesar 1.002 dan koefisien regresi (nilai b) adalah sebesar 0.217. Dari hasil tersebut dapat dirumuskan persamaan regresi linear sederhana sebagai berikut:

$$
\hat{\mathbf{Y}}=1.002+0.217 \mathbf{X}_{1}
$$

Persamaan regresi linear sederhana ini menunjukkan bahwa pengaruh harga terhadap keputusan membeli adalah searah dan positif. Ini berarti setiap adanya kenaikan pada harga akan meningkatkan keputusan membeli.

Hasil perhitungan mengidentifkasikan bahwa nilai a (konstanta) 1.002, berarti jika tidak ada perubahan pada harga, maka keputusan membeli 1.002. Nilai $b_{1} \quad 0.217$ menunjukkan adanya pengaruh positif harga terhadap keputusan membeli, berarti bahwa setiap kenaikan satu satuan pada harga, akan meningkatkan keputusan membeli 0.217 .

2. Mutu Produk Terhadap Keputusan Membeli

Hasil regresi dapat dilihat bahwa besarnya nilai konstanta (nilai a) 2.519 dan koefisien regresi (nilai b) adalah 0.067. Dari hasil tersebut dapat dirumuskan persamaan regresi linear sederhana berikut:

$$
\hat{\mathbf{Y}}=2.519+0.067 \mathbf{X}_{2}
$$

Persamaan regresi linear sederhana ini menunjukkan bahwa pengaruh mutu produk terhadap keputusan membeli adalah searah dan positif. Ini berarti setiap adanya kenaikan pada mutu produk akan meningkatkan keputusan membeli.

Hasil perhitungan mengidentifkasikan bahwa nilai a (konstanta) 2.519. Berarti jika tidak ada perubahan pada mutu produk, maka keputusan membeli 2.519. Nilai b2 0.067 menunjukkan adanya pengaruh positif mutu produk terhadap keputusan membeli, berarti bahwa setiap kenaikan satu satuan pada mutu produk maka akan meningkatkan keputusan membeli 0.067 .

3. Bauran Promosi Terhadap Keputusan Membeli Hasil regresi dapat dilihat bahwa besarnya nilai konstanta (nilai a) 2.886 dan koefisien regresi (nilai b) adalah 0.122. Dari hasil tersebut dapat dirumuskan persamaan regresi linear sederhana berikut:

$$
\hat{\mathbf{Y}}=2.886+0.122 \mathrm{X}_{2}
$$

Persamaan regresi linear sederhana ini menunjukkan bahwa pengaruh bauran promosi terhadap keputusan membeli adalah searah dan positif. Ini berarti setiap adanya kenaikan pada bauran promosi akan meningkatkan keputusan membeli.

Hasil perhitungan mengidentifikasikan bahwa nilai a (konstanta) 2.886 berarti jika tidak ada perubahan pada bauran promosi, maka keputusan membeliakan 2.886. Nilai $b_{2} \quad 0.122$ menunjukkan adanya pengaruh positif mutu produk terhadap keputusan membeli. Berarti bahwa setiap kenaikan satu satuan pada mutu produk maka akan meningkatkan keputusan membeli 0.122 .

\section{Uji Regresi Linnier Berganda}

Analisis regresi linear berganda digunakan untuk meramalkan bagaimana fluktuasi variabel dependen melalui dua atau lebih variabel independen. Dalam penelitian ini ada empat varabel independen yang digunakan, yaitu harga, mutu produk, bauran promosi, dan citra merk, sedangkan yang menjadi variabel dependennya keputusan membeli.

Dari hasil perhitungan SPSS dapat diperoleh rumusan persamaan regresi linear berganda untuk variabel independen (harga, mutu produk, bauran promosi, citra merk) terhadap variabel dependen (keputusan membeli) sebagai berikut: $\hat{\mathbf{Y}}=0.865+0.203 \mathbf{X}_{1}+0.011 \mathbf{X}_{2}+0.042 \mathbf{X}_{3}-0.066 \mathbf{X}_{4}$

Hasil perhitungan analisis mengidentikasikan bahwa nilai a (konstanta) 0.865. Berarti jika tidak ada variabel independen harga, mutu produk, bauran promosi, dan citra merk, maka 
keputusan membeli 0.865. Nilai $b_{1}$ (koefisien harga) 0.203 menunjukkan adanya pengaruh positif atau penerimaan harga terhadap keputusan membeli. Berarti bahwa tiap kenaikan satu satuan pada harga akan meningkatkan keputusan membeli 0.203. Nilai $b_{2}$ (koefisien mutu produk) 0.011 menunjukkan adanya pengaruh positif mutu produk terhadap keputusan membeli. Berarti bahwa tiap kenaikan satu satuan pada mutu produk akan meningkatkan keputusan membeli 0.011 .

Nilai $b_{3}$ (koefisien bauran promosi) 0.042 menunjukkan adanya pengaruh positif bauran promosi terhadap keputusan membeli. Berarti bahwa tiap kenaikan sebesar satu satuan pada bauran promosi akan meningkatkan keputusan membeli sebesar 0.042 . Nilai b4 (koefisien citra merk) 0.066 menunjukkan adanya pengaruh positif citra merk terhadap keputusan membeli. Berarti bahwa tiap kenaikan satu satuan pada citra merk akan meningkatkan keputusan membeli 0.066 .

\section{Uji Hipotesis dan Analisis}

Uji $\mathbf{t}$

1. Hipotesis penelitian pertama

Hasil uji t pada hasil regresi linear sederhana berikut:

$\mathrm{H}_{1}$ : Terdapat pengaruh harga terhadap keputusan membeli.

Berdasarkan hasil analisis regresi linear sederhana, harga diperoleh koefisien regresi 1.013 dan nilai $t$ hitung $=8.035$ dengan taraf nyata 0.000 . Dengan menggunakan taraf nyata 0.05 , didapat $\mathrm{t}$ tabel 0.677. Ini berarti $\mathrm{t}$ hitung lebih besar dari $\mathrm{t}$ tabel, yaitu 8.035 lebih besar dari 0.677. Berarti Ho ditolak dan Ha diterima. Dengan demikian hipotesis penelitian pertama $\left(\mathrm{H}_{1}\right)$ dapat diterima atau terbukti. Arah koefisien regresi positif berarti bahwa harga memiliki pengaruh nyata dan positif terhadap keputusan membeli. Dengan kata lain dapat disimpulkan bahwa harga penting dan berpengaruh dalam meningkatkan keputusan membeli.

2. Hipotesis penelitian kedua

Hasil uji t dari hasil regresi linier sederhana berikut:

$\mathrm{H}_{2}$ : Terdapat pengaruh mutu produk terhadap keputusan membeli.

Berdasarkan hasil analisis regresi linier sederhana, mutu produk diperoleh nilai koefisien regresi $0.055 \mathrm{dan} t$ hitung $=1.867 \mathrm{~d}$ dengan taraf nyata 0.000 . Dengan menggunakan taraf nyata 0.05 , didapat $t$ tabel 0.677 . Ini berarti $t$ hitung lebih besar dari $t$ tabel, yaitu 1.867 lebih besar dari 0.677. Berarti Ho ditolak dan Ha diterima. Dengan demikian hipotesis penelitian kedua $\left(\mathbf{H}_{2}\right)$ dapat diterima atau terbukti. Arah koefisien regresi positif berarti bahwa mutu produk memiliki pengaruh nyata dan positif terhadap keputusan membeli. Dengan kata lain dapat disimpulkan bahwa mutu produk penting dan berpengaruh dalam meningkatkan keputusan membeli.

3. Hipotesis penelitian ketiga

Hasil uji t dari hasil regresi linier sederhana berikut:

$\mathrm{H}_{3}$ : Terdapat pengaruh bauran promosi terhadap keputusan membeli.

Berdasarkan hasil analisis regresi linier sederhana, bauran promosi diperoleh nilai koefisien regresi 0.212 dan $t$ hitung $=4.333$ dengan taraf nyata 0.000. Dengan menggunakan taraf nyata 0.05 , didapat $t$ tabel sebesar 0.677 . Ini berarti $t$ hitung lebih besar dari $\mathrm{t}$ tabel, yaitu 4.333 lebih besar dari 0.677 , berarti Ho ditolak dan Ha diterima. Dengan demikian hipotesis penelitian ketiga $\left(\mathrm{H}_{3}\right)$ dapat diterima atau terbukti. Arah koefisien regresi positif berarti bahwa bauran promosi memiliki pengaruh nyata dan positif terhadap keputusan membeli. Dengan kata lain dapat disimpulkan bahwa bauran promosi penting dan berpengaruh dalam meningkatkan keputusan membeli.

4. Hipotesis penelitian keempat

Hasil uji t dari hasil regresi linier sederhana berikut:

$\mathrm{H}_{4}$ : Terdapat pengaruh citra merk terhadap keputusan membeli.

Berdasarkan hasil analisis regresi linier sederhana, citra merk diperoleh nilai koefisien regresi sebesar 0.328 dan $t$ hitung $=2.156$ dengan taraf nyata 0.000. Dengan menggunakan taraf nyata 0.05 , didapat $t$ tabel sebesar 0.677 . Ini berarti $t$ hitung lebih besar dari $t$ tabel, 4.333 lebih besar dari 0.677, berarti Ho ditolak dan Ha diterima. Dengan demikian hipotesis penelitian ketiga $\left(\mathrm{H}_{3}\right)$ dapat diterima atau terbukti. Arah koefisien regresi positif berarti bahwa bauran promosi memiliki pengaruh nyata dan positif terhadap keputusan membeli. Dengan kata lain dapat disimpulkan bahwa bauran promosi penting dan berpengaruh dalam meningkatkan keputusan membeli.

\section{Uji F (ANOVA)}

Uji $F$ adalah untuk analisis harga, mutu produk, bauran promosi, citra merk, secara bersama-sama (simultan) mempunyai pengaruh nyata terhadap keputusan membeli. 


\section{Hipotesis penelitian kelima}

$\mathrm{H}_{5}$ : Terdapat pengaruh harga, mutu produk, bauran promosi, dan citra merk secara bersama-sama (simultan) terhadap keputusan membeli.

Hasil pengujian hipotesis dengan menggunakan SPSS Ver. 16.00 pada taraf nyata 5\%, diperoleh $\mathrm{F}$ hitung 174.110 dan signifikansi 0.000 . Nilai $F_{\text {tabel }}$ dilihat pada taraf nyata $5 \%$ dengan $\mathrm{df}$ pembilang (k-2) dan df penyebut (n-k) maka diperoleh $\mathrm{F}_{\text {tabel }}$ yaitu $\mathrm{F}_{(2: 98)}=3.09 . \mathrm{F}_{\text {hitung }}$ lebih besar dariF ${ }_{t a b e l}$, yaitu 174.110 lebih besar dari 3.09 dan signifikansi 0.000 lebih kecil dari 0. 05, berarti Ho ditolak dan Ha diterima. Dengan demikian hipotesis penelitian kelima $\left(\mathrm{H}_{5}\right)$ dapat diterima atau terbukti. Dengan demikian dapat disimpulkan bahwa harga, mutu produk, bauran promosi, dan citra merk, perusahaan secara bersama-sama (simultan) dianggap penting dan berpengaruh nyata dalam meningkatkan keputusan membeli.

\section{Uji R² (Koefisien Determinasi)}

Analisis koefisien determinasi bertujuan menganalisis seberapa besar kemampuan variabel-variabel independen (harga, mutu produk, bauran promosi, dan citra merk) secara bersama-sama dalam menjelaskan variabel dependen (keputusan membeli). Dari hasil analisis dengan menggunakan program SPSS Ver. 16. 00 dapat diperoleh nilai $\mathrm{R}^{2}$ (Adjusted $R$ Square).

Hasil korelasi r 0,938 menunjukkan bahwa secara bersama-sama hubungan harga, mutu produk, bauran promosi, dan citra merk, dengan keputusan membeli mempunyai hubungan positif, searah dan sangat tinggi. Jika nilai harga, mutu produk, bauran promosi, dan citra merk naik, maka nilai keputusan membeli juga akan naik. Nilai koefisien determinasi $\mathrm{R}^{2}$ (adjustedr square) 0,880 atau $88 \%$. Artinya kontribusi variabel-variabel bebas secara bersama-sama, yaitu harga, mutu produk, bauran promosi, dan citra merk, terhadap keputusan membeli adalah $88 \%$, dan sisanya (22\%) dijelaskan oleh variabel lain yang tidak diteliti.

\section{Implikasi Manajerial}

Berdasarkan analisis pembahasan dapat dijelaskan bahwa implikasi secara akademik diharapkan dapat menjadi wacana pengembangan entrepreneur di kalangan mahasiswa khususnya mengenai materi kewirausahaan yang berkaitan dengan faktor-faktor yang berpengaruh pada minat pembelian majalah. Implikasi secara praktik diharapkan dengan penelitian ini dapat menjadi masukan, khususnya bagi manajemen majalah Elshinta untuk lebih mengembangkan isi kewirausahaan yang up to date, sehingga dapat meningkatkan minat baca dan minat beli. Industri media cetak di Indonesia khususnya majalah Elshinta dituntut untuk terus berinovasi, sehingga Majalah Elshinta dapat menjadi preferensi dari pelanggan. Saat ini isi Majalah Elshinta mempunyai sasaran tepat guna bagi pembaca. Dengan mengetengahkan artikel dan narasumber kompeten, pembaca memperoleh inspirasi dan termotivasi.

Selain itu para pembeli majalah ini tertarik membeli karena adanya rubrik profil pengusaha besar dan sukses. Rubrik ini ditulis dengan gaya wawancara dan deskripsi/narasi, dan berisi informasi seputar pengalaman hidup, kiat-kiat sukses, serta filosofi. Hal ini menyemangati pembaca dalam menjalankan wirausaha. Rubrik profil pengusaha ini menekankan pada sisi motivasi dan inspirasi.

Pembaca juga tertarik karena adanya rubrik kewirausahaan Majalah Elshinta yang berisi informasi peluang usaha. Ditulis dengan tema tertentu tentang jenis-jenis usaha yang saling terkait, yaitu informasi usaha menyangkut permodalan, hingga omzet yang diperoleh. Rubrik kewirausahaan ini berisi informasi peluang UKM yang potensial dan layak untuk ditekuni.

Bagi para pengusaha rubrik francise kewirausahaan Majalah Elshinta ini memberikan informasi peluang usaha waralaba. Memiliki potensi dan layak untuk ditekuni, yaitu memuat seputar modal usaha, laba, kendala dan hal-hal lain menyangkut usaha tersebut. Rubrik ini juga menyoroti masalah-masalah khusus, gejala atau trend di dunia waralaba dengan contoh bisnisbisnis unik yang sudah berjalan.

\section{KESIMPULAN}

Dalam mengelola media massa, faktor internal dan eksternal menjadi tantangan bagi pengelola Majalah Elshinta seperti mutu SDM yang tidak memadai, selain itu juga persaingan antar majalah, kenaikan harga bahan baku, dan minat baca masyarakat Indonesia yang rendah.

Berdasarkan hasil analisis regresi linear sederhana, yang diuji dengan uji $t$ didapatkan bahwa harga, mutu produk dan bauran promosi 
berpengaruh nyata dan positif secara parsial terhadap keputusan membeli majalah Elshinta. Dengan uji $\mathrm{F}$ didapatkan bahwa harga, mutu produk, bauran promosi, dan citra merk perusahaan secara bersama-sama (simultan) dianggap penting dan berpengaruh nyata dalam meningkatkan keputusan membeli majalah Elshinta. Dari hasil analisis pengujian dengan menggunakan SPSS didapatkan bahwa terdapat pengaruh positif dan signifikan antara faktor variabel kualitas produk, bauran promosi, dan citra merk terhadap keputusan membeli majalah Elshinta.

Konten kewirausahaan pada majalah Elshinta adalah rubrik yang sangat direkomendasikan bagi pengusaha pemula dalam mencari peluang-peluang bisnis dan referensi bisnis dari tokoh-tokoh kewirausahaan. Untuk itu majalah Elshinta terus berusaha menampilkan usahausaha yang sedang menjadi topik pembicaraan di masyarakat.

\section{DAFTAR PUSTAKA}

Arikunto S. 2006. Prosedur Penelitian Suatu Pendekatan Praktik. Jakarta (ID): Rineka Cipta.

Bonneff M. 1976. Récentes Études et Points de vue sur la" Mentalité Javanaise" et le Problème du Développement National en Indonésie. Archipel. 12(1): 231-248.

Hartono B, Ningsih UW, Septiarini NF. 2011. Perilaku Konsumen dalam Pembelian
Bakso di Malang. Buletin Peternakan. 35(2): 137-142.

Kotler P, Roberto N, Lee N. 2002. Social Marketing: Improving The Quality Of Life. New Jersey (US): Pearson Prentice Hall.

Lestari EP. 2010. Penguatan Ekonomi Industri Kecil dan Menengah Melalui Platform Klaster Industri. Jurnal Organisasi \& Manajemen. 6(2): 146-157.

Mulyana M, Syarif R. 2007. Analisis Sikap dan Perilaku Konsumen Terhadap Pembelian Produk Studi Kasus Produk Susu Kental Manis Coklat Indomilk pada Konsumen Jakarta. Jurnal Ilmiah Kesatuan. 2(9): 108-112.

Noviyarto H. 2010. Pengaruh Perilaku Konsumen Mobile Internet Terhadap Keputusan Pembelian Paket Layanan Data Unlimited Internet CDMA di DKI Jakarta.InComTech. Jurnal Telekomunikasi dan Komputer. 1(2):107129.

Riduwan. 2005. Skala Pengukuran VariabelVariabel Penelitian. Bandung (ID): Alfabeta.

Ritawati T, Hartini S, Muryani. 2001. Analisis Faktor-Faktor yang Mempengaruhi Perilaku Konsumen dalam Pembelian Air Minum Mineral di Kotamadya Surabaya. Jurnal Penelitian Dinamika Sosial. 2(3):48-58.

Shane S, Venkatarman S. 2000. The Promise of Enterpreneurship as a Field of Research. Academy of Management Review. 25(1): 217226.

Suprapto T. 2009. Pengantar Teori \& Manajemen Komunikasi. Yogyakarta (ID): Media Pressindo. 